\title{
7 The impact of global \\ and regional markets on \\ agricultural transformation \\ in Southern Africa
}

\author{
Ferdi Meyer, Tracy Davids and Nick Vink
}

\section{Introduction}

Over the past two decades, agricultural markets, trade and food systems in Southern Africa have experienced dramatic transformation. Most of the region's economies were characterized by periods of relatively fast economic growth (around 3 to $6 \%$ ), increasing population and strong patterns of urbanization that have triggered a diversification in diets. Consumers have progressively added more perishable and processed foods to diets previously dominated by grains and other staples, unleashing a wave of structural transformation of the food system. Consequently, markets responded and a number of countries in the Southern African region have expanded agricultural production beyond what local markets can consume, boosting the value and volume of exports of a wide number of commodities.

In high value commodities such as fruit and wine, the region typically has a resource-based competitive advantage in global exports markets, mainly due to suitable climatic conditions, water for irrigation, relatively low wage rates and, in the case of South Africa, competitive infrastructure. However, countries like Zambia and Angola remain net importers of high-valued and processed agricultural products, yet these countries are barely scratching the surface of their natural resource potential for producing high-value crops. In the case of Zimbabwe, production of high-value crops has dwindled following the introduction of the land grab in the early 2000s. Thus, there is significant opportunity for expansion well beyond what local markets can absorb, yet these countries are faced by poor infrastructure, very little investment in cold chains, complex bureaucratic systems and an inconsistent policy environment that increases the perceived risk for long-term investments in high value crops.

In contrast to high value crops, many countries in the region have made significant progress in increasing production of field crops (e.g., maize, soybeans, sugar, etc.), with the sharp rise in commodity prices and some policy reforms with respect to access to land being the main drivers of change. Predictably, though, most of the increase in production north of South Africa's borders was driven by expansion of the area under production and not by higher yields. 
Figure 7.1 presents the net trade position of total agricultural products for the Southern African Development Community (SADC) region. It illustrates that the region is typically a net exporter of unprocessed products. Whereas imports of processed products increased until 2012, significant investments in midstream and downstream industries, such as a major expansion of soybean crushing facilities, fruit juice concentrate plants, etc., have resulted in a reversal of this trend in recent years. While the region as a whole remains a net importer of processed products, the real net import value of these in 2017 was less than a third of the 2012 value.

Figure 7.2 presents a different view on the net trade for the SADC region by aggregating all agricultural products into 15 commodity groups and illustrating the average net trade position for each commodity group between 2010 and 2017. For specific commodity groups where the region has limited production capacity (such as wheat and rice), or where the competitiveness of domestic value chains is under pressure (such as chicken meat), the region continues to import significant volumes.

At aggregate levels, the changes observed in agricultural trade in recent years reflect growth opportunities arising from the rapid transformation of agricultural markets, major private sector investments throughout the value chain and the rapid adoption of world-class technology. At the same time, a number of critical challenges remain and are in fact becoming more important. Many of these relate to more complex bilateral and multilateral trade negotiations, sanitary and phytosanitary protocols (SPS) and Non-Tariff Trade Measures (NTM's), rules of origin and many more, which will influence the future growth trajectory of the sector. One underlying element of all these challenges relates to effective management, the capacity and the required skills by governments

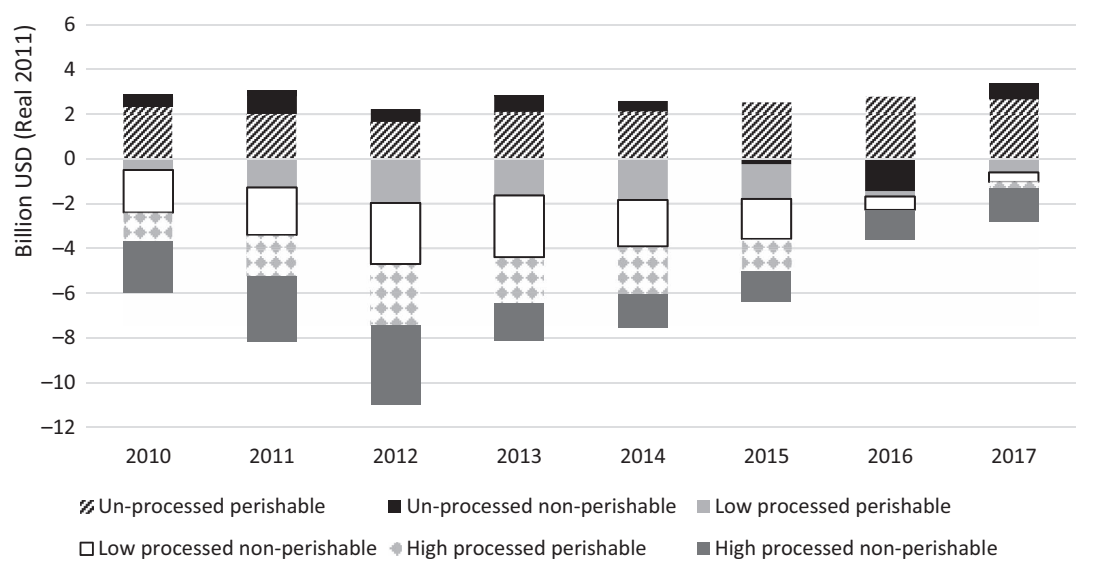

Figure 7.1 Net trade in agricultural products for the SADC region

Source: Compiled from World Integrated Trade Solutions \& World Bank, 2019 


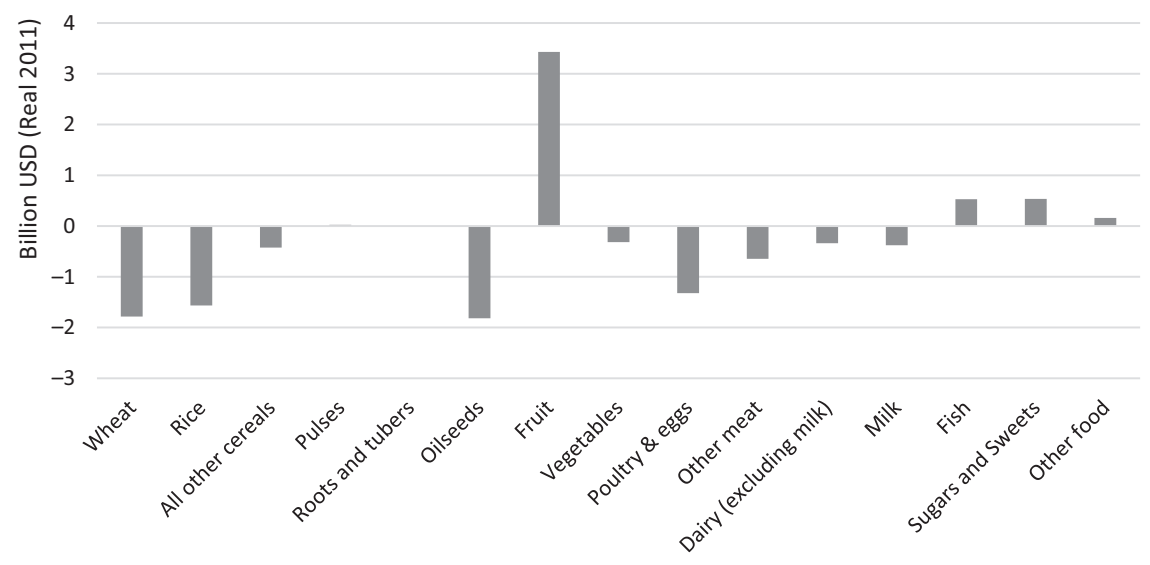

Figure 7.2 Average net trade position of all agricultural products, 2010-2017

Source: Compiled from World Integrated Trade Solutions \& World Bank, 2019

and industry to address these issues effectively. Countries that do not have the capacity to deal with these issues effectively will over the long run lose out on growing export markets and will face increasing competition from imports.

These challenges and opportunities are best illustrated through case studies of three key commodities where rapid transformation has been evident over the past decade.

\section{Commodity specific case studies}

These case studies are based on three commodity groups that reflect a spectrum of imported and exported products. The first is vegetable oil, where the SADC region remains a net importer, despite significant investment in oilseed processing facilities in a number of individual countries. The second is citrus, the largest contributing industry to the net export position of fruit products and a key sector driving agricultural growth in South Africa in recent years. The third is beef, where a number of countries reflect remarkable export driven growth, but substantial opportunities remain unutilized due to a lack of market access.

\section{Vegetable oil}

Since 2007, the value of vegetable oil imports into the SADC region has increased by almost 3\% per year. In many countries, investments have occurred in response to the development of domestic value chains and growing supply. In South Africa, for example, dedicated soybean crushing capacity increased from 340,000tonnes in 2012 to 1.8 million tonnes in 2017. In Zambia, oilseed crushing capacity expanded from 125,000 tonnes in 2010 , to 375,000 tonnes 
in 2016, and in Malawi, from 95,000 tonnes in 2010 to 465,000 tonnes in 2016 (Meyer et al., 2018).

Despite the expansion in processing facilities, crush volumes in most of these countries remain well below capacity. In South Africa, soybean production growth of almost 15\% per annum has still been insufficient to ensure optimal utilization of the installed crush capacity, but in 2017, the domestic crop of 1.5 million tonnes came close. The sharp increase in local crushing has reversed the increasing trend in imported soybean meal for the feed industry and, compared to import levels around 950,000 tons of soybean meal six years ago, imports have declined to around 450,000 tons. In its latest baseline, the Bureau for Food and Agricultural Policy (BFAP) projects that South Africa can become self-sufficient in soybean meal within the next five years (BFAP, 2018).

In Zambia and Malawi however, rapid soybean production growth has resulted in growing soybean exports, despite surplus crush capacity. Both Malawi and Zambia remain net importers of vegetable oil, but the demand for animal feed from the intensive livestock sectors (poultry, eggs, dairy, pig meat) has not yet expanded at the same rate as soybean production - yielding a surplus of soybean oilcake (Table 7.1). The reason for this is that both countries have a small intensive livestock industry relative to the amount of feed they can produce. For instance, a substantial share of Zambia's poultry production has also transformed into a highly intensive operation, total production amounts to approximately 100,000 tons, which is sufficient to supply the local demand for chicken meat. Therefore, if the government of Zambia will not actively drive potential export markets for chicken meat into the region and boneless portions into the EU markets, the potential for value addition of soybeans and meal will be limited.

Table 7.1 Soybean production and trade in South Africa, Zambia and Malawi

\begin{tabular}{|c|c|c|c|c|c|c|c|}
\hline & & \multicolumn{2}{|c|}{ South Africa } & \multicolumn{2}{|l|}{ Zambia } & \multicolumn{2}{|l|}{ Malawi } \\
\hline & & $\begin{array}{l}\text { Average } \\
2015-17\end{array}$ & $\begin{array}{l}\text { 10-year } \\
\text { growth p.a. }\end{array}$ & $\begin{array}{l}\text { Average } \\
2015-17\end{array}$ & $\begin{array}{l}\text { 10-year } \\
\text { growth p.a. }\end{array}$ & $\begin{array}{l}\text { Average } \\
2015-17\end{array}$ & $\begin{array}{l}\text { 10-year } \\
\text { growth p.a. }\end{array}$ \\
\hline $\begin{array}{l}\text { Soybean } \\
\text { production }\end{array}$ & $1000 \mathrm{t}$ & 1042.67 & $14.99 \%$ & 281.74 & $16.77 \%$ & 116.51 & $-1.27 \%$ \\
\hline Soybean area & 1000 ha & 588.02 & $13.20 \%$ & 168.97 & $17.78 \%$ & 131.27 & $0.27 \%$ \\
\hline Soybean yield & t/ha & 1.78 & $1.79 \%$ & 1.70 & $-1.01 \%$ & 0.89 & $-1.55 \%$ \\
\hline \multicolumn{8}{|l|}{ Imports } \\
\hline Soybeans & $1000 \mathrm{t}$ & 161.44 & $24.8 \%$ & 0.77 & $-19.5 \%$ & 0.36 & $-28.3 \%$ \\
\hline Soybean meal & $1000 \mathrm{t}$ & 545.64 & $-6.8 \%$ & 1.11 & $-7.9 \%$ & 0.70 & $-60.4 \%$ \\
\hline Soybean oil & $1000 \mathrm{t}$ & 187.93 & $-2.9 \%$ & 16.94 & $4.2 \%$ & 12.42 & $-2.7 \%$ \\
\hline \multicolumn{8}{|l|}{ Exports } \\
\hline Soybeans & $1000 \mathrm{t}$ & 5.25 & $-3.9 \%$ & 34.01 & $25.5 \%$ & 14.00 & $23.2 \%$ \\
\hline Soybean meal & $1000 \mathrm{t}$ & 82.522 & $26.0 \%$ & 54.686 & $106.1 \%$ & 15.266 & $56.0 \%$ \\
\hline Soybean oil & $1000 \mathrm{t}$ & 71.15 & $41.5 \%$ & 0.70 & $-12.1 \%$ & 0.00 & NA \\
\hline
\end{tabular}

Source: Compiled from SAGIS, 2019; ReNAPRI, 2018; ITC Trademap, 2019 
Currently, the surplus is typically exported to South Africa, resulting in growing intraregional trade, but high transport costs (freight rates, waiting time at the border, etc.) in the region implies that price levels, and consequently also crush margins, decline sharply when surpluses have to be exported. As a result, production growth has stagnated in recent years.

Going forward, rapid growth in South African soybean production is projected to take the country to self-sufficiency in soybean meal, implying that current regional exporters such as Zambia and Malawi will likely need to find new markets for their products, either domestically or elsewhere in the region. Domestic consumption would, of course, require substantial growth in intensive livestock production, which is possible if current trends in agricultural transformation continue. However, exports into the rest of the Southern African region would benefit from investments that reduce the cost of trade.

While the region arguably has the potential to produce and process enough oilseeds to also become self-sufficient in vegetable oil, it will continue to be challenged by highly competitive palm oil imports from other parts of the world (e.g., Indonesia and Malaysia). This is particularly relevant to high oil yielding seeds such as sunflower and canola.

\section{Citrus}

In its National Development Plan, compiled in 2012 (NDP, 2012), South Africa's National Planning Commission identified a number of high value, export orientated commodities with significant growth potential. Citrus represents the largest industry among these and is currently the leading contributor to South Africa's agricultural exports. Table 7.2 indicates that, over the past decade, exports of oranges have increased by nearly $2 \%$ per year, while the exports of other citrus products increased by almost $5 \%$ per year. The increase in export

Table 7.2 Growth in the South African citrus industry

\begin{tabular}{|c|c|c|c|c|c|}
\hline & & \multicolumn{2}{|l|}{ Oranges } & \multicolumn{2}{|l|}{ Other citrus ${ }^{1}$} \\
\hline & & $\begin{array}{l}\text { Average } \\
2015-2017\end{array}$ & $\begin{array}{l}\text { 10-year avg. } \\
\text { growth p.a. }\end{array}$ & $\begin{array}{l}\text { Average } \\
2015-2017\end{array}$ & $\begin{array}{l}\text { 10-year avg. } \\
\text { growth p.a. }\end{array}$ \\
\hline Production & 1000 tons & 1427.67 & $1.05 \%$ & 919.21 & $3.34 \%$ \\
\hline Area & 1000 ha & 43.79 & $1.54 \%$ & 29.09 & $5.68 \%$ \\
\hline Yield & t/ha & 32.65 & $-0.49 \%$ & 31.91 & $-2.35 \%$ \\
\hline $\begin{array}{l}\text { Domestic fresh } \\
\text { consumption }\end{array}$ & 1000 tons & 95.88 & $-3.75 \%$ & 48.18 & $8.38 \%$ \\
\hline $\begin{array}{l}\text { Domestic } \\
\text { processing }\end{array}$ & 1000 tons & 262.93 & $-0.10 \%$ & 233.11 & $-0.67 \%$ \\
\hline Exports & 1000 tons & 1068.86 & $1.73 \%$ & 637.91 & $4.77 \%$ \\
\hline
\end{tabular}

1 Soft Citrus, Grapefruit, Lemons and Limes

Source: Compiled from BFAP, 2018 
value was even greater, supporting significant area expansion. Many parts of South Africa possess the climatic conditions and natural resource base to produce citrus successfully, and at different times of the year, provide a comprehensive portfolio of products through most of the year. The labour intensive nature of production provides South Africa with a competitive advantage, allowing the country to become the second largest exporter of fresh citrus fruit in the world after Spain.

While the citrus industry is an undoubted success story within South African agriculture, it remains challenged by a number of factors. The prevalence of Citrus Black Spot (CBS), a fungal disease that predominantly affects the rind of fruit, has led to the implementation of a number of costly compliance measures to retain access to South Africa's largest export markets in the EU. As an alternative and diversification strategy, producers have targeted Asian markets for export growth. However, many of South Africa's competitors in the Southern Hemisphere, such as Chile, Peru and Australia, have been more successful in negotiating preferential access into these Asian markets, leaving South Africa's producers at a competitive disadvantage.

Other challenges that the industry will have to address is the effective use of water. In a recent agricultural census undertaken in the Western Cape Province, flyover and remote sensing data shows clear shifts of orchards out of wine production into citrus over the past five years. The water demand per hectare is much higher for citrus trees than for wine grapes, and through closer analysis of the data, it is evident that the total area under irrigation has in fact decreased over the past five years due to this increased demand for water per hectare and changing cropping patterns. Apart from a handful of new water infrastructure investments and the revitalization of existing idle irrigation schemes, South Africa will mainly have to achieve further expansion in irrigation of high valued crops by effective maintenance of existing irrigation infrastructure and the implementation of water saving technology.

\section{Beef}

At aggregate level, the SADC region remains a net importer of beef products, but selected countries have been very successful in driving export growth. The most prolific of these is South Africa, which increased beef product exports by an annual average of 27\% between 2007 and 2017 (BFAP, 2018). Most of this beef is produced in intensive feedlot operations that are responsible for approximately $80 \%$ of all beef that is produced in South Africa. In contrast, beef production in Botswana and Namibia is mainly characterized by extensive pasture-based systems. Both of these countries have also been successful in building export-orientated beef industries, though adverse weather conditions over the past five years have limited export growth. Nevertheless, they have established good market access and continue to export premium products very successfully into the EU in particular. Furthermore, it is also important to note that there is significant intraregional trade in live animals. For example, South 
Table 7.3 Beef export growth in South Africa, Namibia, Botswana and Zambia

\begin{tabular}{llc}
\hline & $\begin{array}{l}\text { Average 2012-2017 } \\
\text { ('000 tons) }\end{array}$ & 10-year avg. growth p.a. (\%) \\
\hline South Africa & 31.55 & 27 \\
Namibia & 18.84 & -6 \\
Botswana & 25.00 & 1 \\
Zambia & 0.08 & 19 \\
\hline
\end{tabular}

Source: Compiled from ITC Trademap, 2019

African feedlots are importing in the order of 200,000 weaner calves annually because feed costs are significantly lower in South Africa than in Namibia.

The beef industry in Zambia has also transformed significantly over the past decade, mainly due to higher maize and soybean production, which has boosted the production of beef in feedlots. Exports are still small in absolute terms but have grown impressively at just under $20 \%$ per annum over the past decade (Table 7.3).

One of the greatest challenges facing beef exports from the Southern African region is the prevalence of Foot and Mouth Disease (FMD), which poses challenges in complying with the SPS protocols of many importing countries. The often close proximity of cattle to buffalo, which carry the disease, makes it difficult to control. In Botswana and Namibia, the challenges associated with FMD have been overcome by compartmentalization and zoning, combined with strong traceability systems. This has allowed both countries access to the EU market, where they obtain a premium for grass fed beef exported from the FMD free zones. In both countries, government entities have played a key role in beef exports.

South Africa also utilizes a zoning system. FMD remain endemic to the Kruger National Park, but a protection zone has been established around the park and the World Organisation for Animal Health (OIE) declared the rest of the country free of FMD without vaccination in 2014 (DAFF, 2015). Consequently, exports expanded rapidly, first into high value markets in the Middle East and later into China. This growth in exports has supported prices, despite challenging weather conditions and herd liquidation in 2015 and 2016. Unlike Namibia however, South Africa does not have a centralized traceability system and, hence, is not able to access premium markets such as the EU and the USA. Had these markets been accessible to South African producers, both exports and production would have performed even better.

\section{Conclusion}

The agricultural sector in South Africa is changing rapidly, driven by changing patterns of demand that have come about as a result of demographic change, especially rapid urbanization and the rise of a middle class with sufficient 
disposable income. This has set in motion a number of fundamental changes in the food retail sector, giving rise to a "supermarket revolution" that started more than a decade ago and had already spread into secondary cities and the larger towns (Weatherspoon and Reardon, 2003) because of the liberalization of foreign direct investment rules and the rise of the middle class.

In this chapter, we have provided three case studies (vegetable oils, citrus and beef) which illustrate how production and trade patterns are changing in reaction to the changes in the structure of demand. The changes are not uniformly positive and are often retarded by poor infrastructure and excessive bureaucracy but generally point to potential positive changes.

\section{References}

BFAP. (2018) BFAP Baseline: Agricultural Outlook 2018-2027. Bureau for Food and Agricultural Policy, Pretoria.

International Trade Council (ITC). (2019) Trademap Database. [Online] Available at: www. trademap.org.

Meyer, F.H., Traub, L.N., Davids, T., Chisanga, B., Kachule, R., Tostao, E., Vilanculos, O., Popat, M., Binfield, J. and Boulanger, P. (2018) Modelling Soybean Markets in Eastern and Southern Africa. Regional Network of Agricultural Policy Research Institutes (ReNAPRI), EUR 28978 EN. doi:10.2760/20598.

National Planning Commission: South African Presidency. (2012) National Development Plan 2030 Our Future - Make It Work. Government of South Africa. ISBN: 978-0-621-41180-5.

Regional Network of Agricultural Policy Research Institutes (ReNAPRI). (2018) Unpublished Database.

South African Department of Agriculture, Forestry and Fisheries (DAFF). (2015) Media Briefing on the Status of Foot and Mouth Disease in South Africa - 13 January. [Online] Available at: www.nda.agric.za/docs/media/Media\%20brief\%20on\%20FMD.pdf.

South African Grain Information Service (SAGIS). (2019) Historic Production Database. [Online] Available at: www.sagis.org.za/historic $\% 20$ hectares $\% 20 \& \% 20$ production $\% 20$ info.html.

Weatherspoon, D.D. and Reardon, T. (2003) The Rise of Supermarkets in Africa: Implications for Agrifood Systems and the Rural Poor. Development Policy Review 21(3).

World Bank. (2019) World Development Indicators Database. [Online] Available at: https:// databank.worldbank.org/data/reports.aspx? source $=$ world-development-indicators .

World Integrated Trade Solutions (WITS). (2019) World Integrated Trade Solutions Database. [Online] Available at: https://wits.worldbank.org/. 